\title{
AMINO ACIDS, AMINES AND PEPTIDES OF RAM EPIDIDYMAL SEMEN*
}

\author{
H. NEUMARK AND H. SCHINDLER \\ The Volcani Institute of Agricultural Research, Rehovot, Israel
}

(Received 25th May 1967)

Epididymal semen was obtained from rams with a fistula present in the vas. deferens (Tadmor \& Schindler, 1966). It was deproteinized immediately, and the protein-free clear supernatant evaporated to dryness in vacuo at a temperature not exceeding $55^{\circ} \mathrm{C}$. The residue was taken up with about $10 \mathrm{ml}$ water, and the solution thus obtained used for determination of both amines and amino acids.

For the determination of amino acids, the solution was once more dried in vacuo, and the residue taken up with $3 \mathrm{ml} 75 \%$ ethanol. Two-dimensional chromatograms of two samples were run, using $0.2 \mathrm{ml}$ of the final solution, according to Mizell \& Simpson (1961).

For the determination of the amines, the solution was extracted by the method of Yoshinaga, Itoh, Ishida, Sato \& Wada (1961), slightly modified (Neumark, 1964).

After three extractions with ethyl acetate $(50 \mathrm{ml}$ each time), the combined material was evaporated to dryness in vacuo, the residue taken up with $1 \mathrm{ml}$ absolute methanol, and the solution thus obtained used for chromatography. Descending chromatograms were run using two $0.4 \mathrm{ml}$ samples; the solvent mixture used was composed of n-butanol : glacial acetic acid: water (12:3:5). The dried chromatograms were treated with a solution of ninhydrin $(0 \cdot 2$ $\mathrm{g} / 100 \mathrm{ml}$ acetone) containing $10 \%(\mathrm{v} / \mathrm{v})$ glacial acetic acid. The sheets were dried at $110^{\circ} \mathrm{C}$ for $4 \mathrm{~min}$.

For the determination of peptides, the epididymal semen was deproteinized by saturation with ammonium sulphate. After removal of the precipitate, the supernatant was dialysed against constantly flowing distilled water for $36 \mathrm{hr}$. The non-dialysable material was evaporated in vacuo, and the residue taken up. with $75 \%$ ethanol. The solution thus obtained served for chromatography. About $2 \mathrm{ml}$ was applied to a paper sheet and chromatographed in one direction. The different peptides were spotted by developing small reference strips of the chromatogram. The corresponding areas in the main chromatogram were cut out and eluted with $75 \%$ ethanol. After evaporating the ethanol, the peptides were hydrolysed for $22 \mathrm{hr}$ at $110^{\circ} \mathrm{C}$ in vacuo and in the hydrolysate

* Contribution from The National and University Institute of Agriculture, Rehovot, Israel. 1967 Series, No. 1135-E. 
the amino acids determined with an automatic Beckman Amino Analyser. Molecular weight estimation of one of the major peptides was carried out by gel-filtration with Sephadex G-75.

The following results were obtained:

(i) Amino acids. Seventeen ninhydrin-reactive spots were detected. Twelve of these were identified as histidine, cysteic acid, arginine, aspartic acid, glycine, serine, glutamic acid, tyrosine, methionine, and components of the leucine group.

\section{TABLE 1}

AMINO ACID GOMPOSITION OF THREE PEPTIDES EXTRACTED FROM RAM EPIDIDYMAL SEMEN

\begin{tabular}{|c|c|c|c|}
\hline \multirow[b]{2}{*}{ Amino acid } & \multicolumn{3}{|c|}{$\mu$ moles $/ 0.2 \mathrm{ml}$ fuid } \\
\hline & $\begin{array}{c}\text { Peptide } I \\
\left(R_{F} 0.21\right)\end{array}$ & $\begin{array}{l}\text { Peptide II } \\
\left(R_{F} 0.29\right)\end{array}$ & $\begin{array}{l}\text { Peptide III } \\
\left(R_{F} 0.34\right)\end{array}$ \\
\hline $\begin{array}{l}\text { Lysine } \\
\text { Histidine } \\
\text { Arginine } \\
\text { Cysteic acid } \\
\text { Aspartic acid } \\
\text { Threonine } \\
\text { Serine } \\
\text { Glutamic acid } \\
\text { Proline } \\
\text { Glycine } \\
\text { Alanine } \\
\text { Half cystine } \\
\text { Valine } \\
\text { Methionine } \\
\text { Isoleucine } \\
\text { Leucine } \\
\text { Tyrosine } \\
\text { Phenylalanine }\end{array}$ & $\begin{array}{c}0.0034 \\
\text { trace } \\
- \\
\overline{0} \\
0.0055 \\
0.0032 \\
0.0192 \\
0.0075 \\
\text { trace } \\
0.0160 \\
0.0069 \\
- \\
\text { trace } \\
-\overline{0} \\
0.0010 \\
0.0020 \\
\text { trace } \\
\text { trace }\end{array}$ & $\begin{array}{c}0.0124 \\
\text { trace } \\
- \\
\text { trace } \\
0 \cdot 0234 \\
0.0187 \\
0.0260 \\
0.0247 \\
\text { trace } \\
0 \cdot 0448 \\
0.0332 \\
-\overline{0} \\
0 \cdot 0090 \\
0.0492 \\
0.0090 \\
0.0161 \\
- \\
-\end{array}$ & $\begin{array}{c}0.0068 \\
0.0025 \\
\text { trace } \\
\text { trace } \\
0.0088 \\
0.0046 \\
0.0124 \\
0.0096 \\
\text { trace } \\
0.0159 \\
0.0128 \\
- \\
0.0033 \\
\text { trace } \\
0.0035 \\
0.0061 \\
\text { trace } \\
\text { trace }\end{array}$ \\
\hline
\end{tabular}

(ii) Amines. Three amines were detected, the $R_{F}$ values of the two different samples being $0.79(0.82), 0.25(025)$ and $0.12(0.13)$. The compound with the highest $R_{F}$ value seems to resemble ephedrine. The compound with the lowest $\mathbf{R}_{\mathbf{F}}$ value could be an imidazole derivative; in its behaviour on chromatograms it resembled histamine and related compounds.

(iii) Peptides. Four to six peptides were detected by one-dimensional paper chromatography (solvent system-butanol:acetic acid:water (12:3:5); the amino acid composition of the three major peptides is given in Table 1. When a two-dimensional chromatogram was run, using methyl-ethylketone: butanol: water $(2: 2: 1)$ as the second system, two additional spots were detected. The molecular weight of one of the three major peptides mentioned above was estimated by gel filtration to be about 3000 .

The presence of a large number of free amino acids in ram epididymal semen raises the question of their possible role as a source of energy for the epididymal spermatozoa; it is known that the ram epididymal semen contains only very little reducing sugar (White \& Wales, 1961), but that according to 
Mann (1964) "free amino acids represent an extracellular oxidizable substitute for the aerobic metabolism of spermatozoa". The amines may perhaps be formed by decarboxylation of amino acids. Some peptides are known to be of physiological importance (Fruton \& Simmonds, 1960), and it is not unlikely, therefore, that those present in epididymal semen may also be biologically active.

This investigation was supported by a grant from the United States Department of Agriculture under P.L. 480. The skilful help of Mrs Pia Holstein is gratefully acknowledged.

\section{REFERENCES}

Fruton, J. S. \& Simmonds, S. (1960) General biochemistry, 2nd edn, pp. 140-141. Wiley, New York. MANN, T. (1964) The biochemistry of semen and of the male reproductive tract, p. 166. Methuen, London. Mizele, M. \& Simpson, S. B., JR (1961) Paper chromatographic separation of amino acids. A solvent to replace phenol. 7. Chromat. 5, 157.

Neumark, H. (1964) Compounds of low molecular weight in forage crops and their importance in the ensiling process. Ph.D. thesis, Hebrew University, Jerusalem. (Hebrew with Summary in English).

TAdmor, A. \& Schindler, H. (1966) Establishment of a fistula in the vas deferens of rams. Israel $\mathcal{F}$. agric. Res.-Ktavim, 16, 157.

White, I. G. \& Wales, R. G. (1961) Comparison of epididymal and ejaculated semen of the ram. 7. Reprod. Fert. 2, 225.

Yoshinaga, K., Itoh, C., Ishida, N., Sato, T. \& Wada, Y. (1961) Quantitative determination of metadrenalin and normetadrenalin in normal urine. Nature, Lond. 191, 599. 